10 Social Trends, No 3. London, HMSO, 1972.

${ }^{11}$ Heaton, $\mathrm{K}$ W, in Clinical Gastroenterology, ed I A D Bouchier, vol 2, chapt 4. London, Saunders, 1973.

12 Sjovall, H, and Wihman, G, Acta Pathologica et Microbiologica Scandinavica, 1934, suppl No 20.

13 Nakayama, F, and Miyake, H, American fournal of Surgery, 1970, 120, 794

14 Watkinson, G, in Proceedings of III World Congress on Gastroenterology, vol 4, p 157. Tokyo, 1966.
15 Malhotra, S L, Gut, 1968, 9, 290.

16 Sturdevant, R A L, Pearce, M L, and Dayton, S, New England fournal of Medicine, 1973, 288, 24.

17 Friedman, G D, Annals of Internal Medicine, 1968, 68, 222.

${ }^{18}$ Fleming, G W T H, Fournal of Pathology and Bacteriology, 1930, 33, 197.

19 Coyne, M J, et al, New England fournal of Medicine, 1975, 292, 604.

20 Cleave, T L, and Campbell, G D, Diabetes, Coronary Thrombosis and the Saccharine Disease. Bristol, Wright, 1969.

\title{
Isoimmune haemolysis in pathogenesis of anaemia after cardiac surgery
}

\author{
B J BOUGHTON, P R GALBRAITH
}

British Medical fournal, 1975, 4, 430-432

\section{Summary}

A patient who had received multiple transfusions developed antiglobulin-positive haemolytic anaemia due to a delayed haemolytic transfusion reaction. Many cases of haemolytic anaemia after cardiac surgery could be explained on this basis.

\section{Introduction}

Haemolytic anaemia after cardiac surgery occurs in up to $10^{\circ}$ o of cases. ${ }^{1}$ It is caused by mechanical fragmentation of erythrocytes in association with the malfunction of prosthetic heart valves or with persistent bare areas of synthetic graft material. Occasionally valve dysfunction or bare-area lesions are not present, ${ }^{2}$ and a positive direct reaction to antihuman globulin (AHG) develops. The following case helps to explain the pathogenesis of this syndrome.

\section{Case report}

A 43-year-old woman gave a history of acute rheumatic fever at 10 years of age. At 30 years she developed cardiac failure during her sixth pregnancy, but the pregnancy proceeded normally without evidence of haemolytic disease of the newborn. When she was 31 a mitral valvotomy was followed by a transient postcardiotomy syndrome with pericarditis, pleurisy, and fever. Seven years later she received two units of blood for an iron deficiency anaemia of $7.2 \mathrm{~g} / \mathrm{dl}$ and heart failure due to progressive valve disease. The direct $\mathrm{AHG}$ test and antibody screening gave negative results, and with ferrous sulphate the haemoglobin rose to $13.7 \mathrm{~g} / \mathrm{dl}$. At the age of 42 she was not anaemic when a follicular ovarian cyst was removed. A year later, when heart failure followed the onset of atrial fibrillation, mitral valve replacement and tricuspid annuloplasty were planned. Hepatomegaly without splenomegaly was noted, and preoperative investigations gave the following results: haemoglobin $14.8 \mathrm{~g} / \mathrm{dl}$, reticulocytes $1.8^{\circ} \%$, white blood count (WBC) $6.6 \times 10^{9} / 1\left(6600 / \mathrm{mm}^{3}\right)$, platelets $239 \times 10^{9} / 1\left(239000 / \mathrm{mm}^{3}\right)$, normal smear appearances, serum iron $10.4 \mu \mathrm{mol} / \mathrm{l}(58 \mu \mathrm{g} / 100 \mathrm{ml})$, unsatured iron binding capacity $64.3 \mu \mathrm{mol} / \mathrm{l}$ $(359 \mathrm{\mu g} / 100 \mathrm{ml})$. Her blood group was A positive, and the direct AHG test and antibody screening test were negative. Biochemical screening showed nothing abnormal except a mildly increased serum aspartate aminotransferase (SGOT) and lactate dehydrogenase $(\mathrm{LDH})$; she was euthyroid.

Division of Hematology, Department of Medicine, Queen's University, Kingston, Ontario, Canada

B J BOUGHTON, MRCP, MRCPATH

P R GALBRAITH, MD, FRCP(c), division chairman
In a routine operation, with one and a half hours' bypass time, the mitral valve was replaced with Caged Cutter valve, and tricuspid annuloplasty was performed. Postoperatively she received ampicillin and cloxacillin each $0.5 \mathrm{~g}$ six hourly, and warfarin anticoagulation was started on the second day. On the 7th day she developed bronchopneumonia. The sputum contained Pseudomonas aeruginosa and Klebsiella and these responded promptly to gentamycin.

No valvular dysfunction was noted postoperatively, but heart failure did occur when an anaemia started to develop. The haematological progress is summarized in fig 1 . Seven days after operation the haemoglobin was $7.2 \mathrm{~g} / \mathrm{dl}$, reticulocytes $7.9 \%$, erythrocyte sedimentation rate (ESR) $126 \mathrm{~mm} / \mathrm{h}$, WBC $32 \times 10^{9} / 1\left(32300 / \mathrm{mm}^{3}\right)$ (no atypical lymphocytes), and platelets $1178 \times 10^{9} / 1\left(1178000 / \mathrm{mm}^{3}\right)$ The blood (fig 2) showed microspherocytes, polychromasia, nucleated red blood cells, but only rare fragmented red cells. Bilirubin was $115: \mu \mathrm{mol} / \mathrm{l} \quad(6.7 \mathrm{mg} / 100 \mathrm{ml}) \quad($ direct $29 u \mathrm{~mol} / \mathrm{l} \quad(1.7 \mathrm{mg} / 100 \mathrm{ml})$ ) and haptoglobins were $0.5 \mathrm{~g} / 1$ (borderline normal). The plasma haemoglobin, Schumm's test, and urinary-haemosiderin were normal. The direct AHG and antibody screening tests gave positive results, and splenomegaly developed. Steroids were started, but fig 1 shows

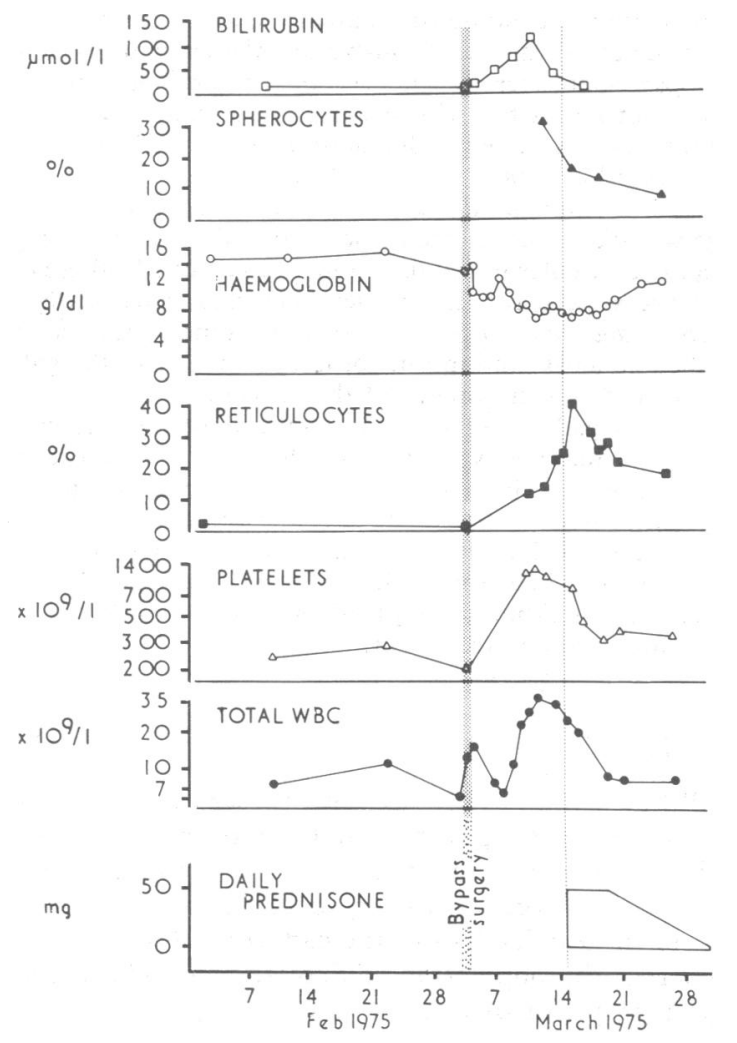

FIG 1-Haematological progress.

Conversion: SI to traditional units-Bilirubin: $1 \mu \mathrm{mol} / \mathrm{l} \approx 0.06 \mathrm{mg} / 100 \mathrm{ml}$. 


\begin{tabular}{|c|c|c|c|c|c|c|}
\hline & History & $\begin{array}{c}\text { Atypical } \\
\text { antibodies }\end{array}$ & $\begin{array}{c}\text { Direct } \\
\text { AHG } \\
\text { test }\end{array}$ & $\begin{array}{c}\text { Units } \\
\text { crossmatched/ } \\
\text { units compatible }\end{array}$ & $\begin{array}{c}\text { Blood } \\
\text { units } \\
\text { given }\end{array}$ & $\begin{array}{c}\text { Transfusion } \\
\text { reaction }\end{array}$ \\
\hline \multirow{2}{*}{$\begin{array}{l}1956-62 \\
1963 \\
1970 \\
1975: \\
3 \text { March } \\
4 \text { March } \\
7 \text { March } \\
11 \text { March } \\
14 \text { March }\end{array}$} & $\begin{array}{l}6 \text { pregnancies } \\
\text { Mitral valvotomy } \\
\text { Iron deficiency }\end{array}$ & $\bar{z}$ & $\bar{z}$ & $\begin{array}{l}4 / 4 \\
2 / 2\end{array}$ & $\begin{array}{l}1 \\
2\end{array}$ & \\
\hline & $\begin{array}{l}\text { Valve replacement } \\
\text { Valve replacement } \\
\text { Valve replacement } \\
\text { Valve replacement } \\
\text { Valve replacement }\end{array}$ & $\begin{array}{c}\bar{z} \\
\overline{+}+ \\
+++\end{array}$ & $\begin{array}{l}- \\
\overline{+} \\
++\end{array}$ & $\begin{array}{c}10 / 10 \\
4 / 4 \\
4 / 4 \\
19 / 0 \\
4 / 1 \mathrm{JK}(\mathrm{a}) \mathrm{neg}\end{array}$ & $\begin{array}{c}6 \\
1 \\
2 \text { packed cells } \\
0 \\
0\end{array}$ & $\begin{array}{c}\text { No immediate reaction } \\
\text { No immediate reaction } \\
\text { No immediate reaction } \\
\text { - }\end{array}$ \\
\hline
\end{tabular}

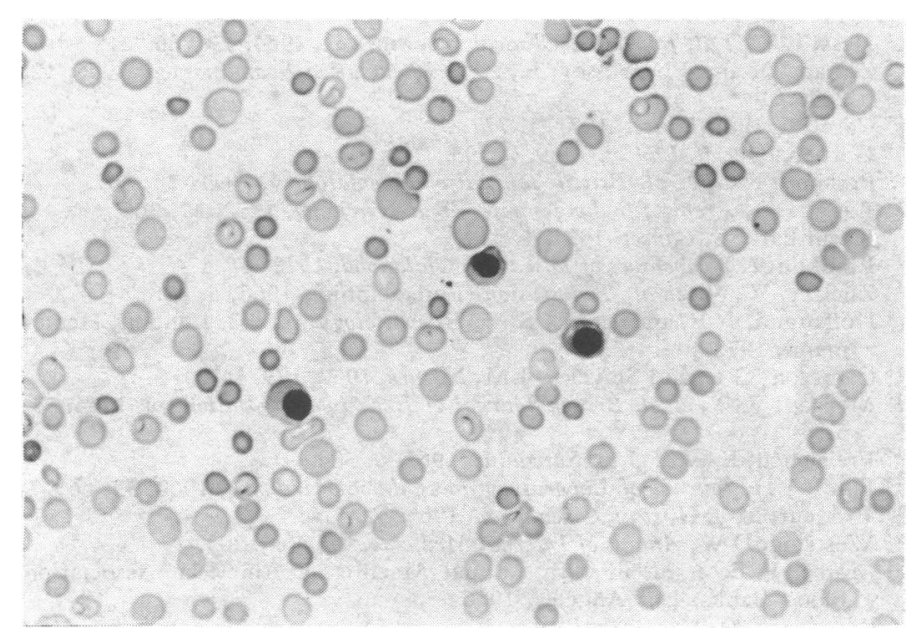

FIG 2-Peripheral blood smear showing spherocytes, polychromatic macrocytes, and normoblasts but no fragmented cells. $(\times 300$. $)$

that many values were improving before this. The cytomegalovirus antibody titre was $1 / 32$ and the Mono spot test for heterophile antibody was negative.

\section{BLOOD TRANSFUSION INVESTIGATIONS}

The transfusion history is presented in the table. When the direct AHG test became positive the antibody screening indicated a possible anti-C specific antibody. Her preoperative red cells grouped as $R_{1} R_{1}$ (CDe/CDe), thus indicating rhesus-specific autoantibody.

Antibody screening in our laboratory using Tencell and Identigen red cell panels indicated anti-Jk(a) and anti- $\mathrm{Lu}(\mathrm{a})$ in the serum and anti-Jk(a) in the red cell eluates. The Canadian Red Cross and Ortho Diagnostics Reference Laboratories confirmed this and further identified cold antibodies of anti-I and anti-P specificity, both acting below $15^{\circ} \mathrm{C}$. The patient's red cells before operation were grouped $A_{1}$, $\mathbf{R}_{1} \mathbf{R}_{1}, \operatorname{JK}(a-b+), L u(a-b+)$, and $P$-negative. These findings were confirmed at follow-up 60 days later. The anti-C antibody was never confirmed and the initial report was thought to be a misinterpretation.

On day 10 four units of Jk(a)-negative blood were crossmatched, but only one was compatible. This unit was reserved but not given to the patient. An expanded direct AHG test on day 10 indicated predominantly IgM and C3 protein on the red cells. Centrifugation of the patient's blood was performed to separate spherocytes from reticulocytes. As judged from appearances in the blood smear an excellent separation was obtained. Eluates from these two fractions were tested in vitro with $\mathrm{Jk}(\mathrm{a}+\mathrm{b}-)$ cells using an AHG technique. The reticulocyte fraction gave \pm reactions, whereas the spherocyte fraction gave $2+$ results. Using an enzyme-AHG technique, and using $\mathrm{Jk}(\mathrm{a}+\mathrm{b}-)$ cells, the serum $\mathrm{Jk}(\mathrm{a})$ antibody titres were as follows: day 1, 0/0; day $7,1 / 64$, day $10,1 / 32$; day $22,1 / 32$; day $62,1 / 1$.

Her clinical improvement paralleled the haematological recovery shown in fig 1 . At follow-up 57 days after the last blood transfusion she was well, and investigations showed: haemoglobin $14 \mathrm{~g} / \mathrm{dl}$, WBC $9 \times 10^{\circ} / 1\left(9000 / \mathrm{mm}^{3}\right)$, platelets $411 \times 10^{\%} / 1\left(411000 / \mathrm{mm}^{3}\right)$, reticulocytes $3.0 \%$, smear normochromic and normocytic, ESR 41 $\mathrm{mm} / \mathrm{h}$, serum iron $15.4 \mu \mathrm{mol} / 1(86 \mu \mathrm{g} / 100 \mathrm{ml})$, unsaturated iron binding capacity $46.4 \mu \mathrm{mol} / 1(259 \mu \mathrm{g} / 100 \mathrm{ml})$, antinuclear factor negative rheumatoid serum factor negative, bilirubin $8.6 \mu \mathrm{mol} / 1(0.5 \mathrm{mg} / 100 \mathrm{ml}$, haptoglobins $1.1 \mathrm{~g} / \mathrm{l}$, direct AHG test negative, serum cytomegalovirus antibody titre $1 / 32$.

\section{Discussion}

In this patient haemolytic anaemia developed without intravascular red cell fragmentation or turbulance at the mitral or tricuspid valves. A specific serum antibody and its elution from red cells indicated an immune haemolytic mechanism. The earliest antibody specificity was not clear, but anti-C antibody was reported. Since the patient's cells were $\mathrm{CDe} / \mathrm{CDe}$ an autohaemolytic process was deduced and steroids were started. It is clear from fig 1, however, that the haemoglobin, the bilirubin, and the spherocytosis had improved before steroids were started, and that the haemolysis was therefore self-limiting. The episode more probably represented a delayed haemolytic transfusion reaction, and this was confirmed by the pretransfusion grouping of the patient's red cells. These were Jk(a)negative, $\mathrm{Lu}(\mathrm{a})$-negative, and $\mathrm{P}$-negative, and, therefore, not susceptible to damage by any of the specific antibodies shown. The cold antibodies only acted at less than $15^{\circ} \mathrm{C}$ and can therefore be disregarded. The anti-Jk(a) eluted from the red cells postoperatively must then have been attached to the cells transfused during the operation. The direct AHG test gave a strongly positive result in the spherocyte fraction of the patient's blood, and the reticulocyte fraction gave a weaker result. These features clearly indicate that the anti-Jk(a) was an isoimmune antibody.

Previous reports are confusing about this syndrome's pathogenesis. Autoimmune haemolysis due to anti-Jk(a) antibody is rare, since only two possible cases have been reported. ${ }^{3}$ The isoimmune character of the anti-Jk(a) in our case, however, seems to be established beyond doubt.

Pirofsky ${ }^{2}$ postulated an autoimmune mechanism in his cases. He considered it to be a graft versus host reaction, mediated by transfused lymphocytes as part of the postcardiotomy syndrome. More current observations on the postcardiotomy syndrome have implicated other mechanisms. Firstly, heart reactive antibodies are almost always found in the presence of the clinical syndrome. ${ }^{4}$ These same antibodies are also found in rheumatoid arthritis, ${ }^{5}$ and in systemic lupus erythematosis, ${ }^{\circ}$ conditions commonly associated with autoimmune haemolysis. Secondly, viruses such as cytomegalovirus ${ }^{7}$ and Epstein-Barr virus ${ }^{8}$ have been implicated. These may have arisen in the blood donors ${ }^{\circ}$ or may have been reactivated in the recipient ${ }^{10}$ during the period of immune suppression that occurs after surgery. ${ }^{11}$ Cytomegalovirus infection is common in other clinical contexts, and two reports ${ }^{12}$ associate it with haemolysis. Our patient, however, was negative for antinuclear factor and rheumatoid serum factor and had no clinical, haematological, or serological evidence of current virus infection. Postcardiotomy syndrome had been diagnosed on a clinical basis 12 years earlier, however.

Ovarian cysts may be associated with haemolytic anaemia, ${ }^{14}$ but these are usually teratomata or dermoid cysts, and removal usually cures the haemolysis. Though cyst fluids do contain blood group substances ${ }^{15-17}$ and can stimulate antibody formation, in our case the antibody studies, the cyst morphology, and the time between ovarian cystectomy and the haemolytic anaemia do not suggest such a mechanism. 
Reticulocytosis may cause a false positive direct AHG test result. ${ }^{18}$ This occurs when the AHG reagent contains antitransferrin which binds to the transferrin found normally on the surface of reticulocytes. Since our positive direct AHG test result was obtained with several reagents, used in different laboratories, this did not appear to be a valid explanation in our case. Furthermore, reticulocyte fractions gave weaker results with AHG than did the spherocyte-rich fractions.

Both Pirofsky ${ }^{2}$ and Brodeur ${ }^{19}$ have suggested that red cell antigenicity might be altered by mechanical damage, resulting in an autoimmune reaction to modified cells. In our case, mechanical fragmentation was not seen so that this explanation is again improbable.

Drug-induced haemolysis would not seem likely in our case because small doses of drugs were used, and antibody testing was not dependent on the presence of drugs in the test system. One irrefutable proof of an autoimmune pathogenesis would be if the haemolysis continued longer than the lifespan of all the transfused blood cells. On this criterion, many previously recorded cases cannot be explained on an autoimmune basis, and delayed haemolytic transfusion reaction is a more likely explanation. In our case haematological recovery was conspicuous 28 days after transfusion, and complete within 43 days, except for the persistence of low titre antibody. Only two previous short reports have suggested isoimmunity as a cause for this syndrome, ${ }^{20}{ }^{21}$ and mechanical red cell fragmentation was present in one of these. Our case clearly shows that isoantibody formation alone can produce marked haemolysis after cardiac surgery and emphasises the careful transfusion management which is required in these cases.
We acknowledge the secretarial help of Mrs Axler and Miss Angold, and the technical expertise of Mr Pat Gribbond. We thank Dr J E Fay, department of medicine, Queen's University, for permission to study this patient.

\section{References}

${ }^{1}$ Marsh, G W, and Lewis, S M, Seminars in Haematology, 1969, 6, 133.

2 Pirofsky, B, et al, New England fournal of Medicine, 1965, 272, 235.

${ }^{3}$ Issitt, P D, Applied Blood Group Serology, Oxnard. California, Spectra Biologicals, 1970.

4 Kaplan, M H, and Dermot Frengley, J, American fournal of Cardiology, 1969, 24, 459 .

5 Hess, E V, et al, fournal of Clinical Investigation, 1964, 43, 886.

${ }^{6}$ Zitnan, D, and Bosmansky, K, Acta Rheumatica Scandinavica, 1966, 12, 267.

${ }^{7}$ Carol, E, et al, Lancet, 1971, 1, 777.

8 Gerber, P, et al, Lancet, 1969, 1, 593.

${ }^{9}$ Perham, T G, et al, British fournal of Haematology, 1971, 20, 307.

10 Lang, D J, Archiv für die gesamte Virus-forschung, 1972, 37, 365.

11 Kwan Park, S, Lancet, 1971, 1, 53.

12 Franklin, A J, Archives of Disease in Childhood, 1972, 47, 474.

${ }_{13}$ Zuelzer, W W, et al, Transfusion (Philadelphia), 1966, 6, 438.

14 Hoffbrand, A F, and Lewis, S M, Haematology, p. 233. London, Heinemann, 1972.

15 Cameron, G L, and Staveley, J M, Nature, 1957, 179, 147.

${ }^{16}$ Morgan, W T, et al, British fournal of Experime:ntal Pathology, 1944, 55, 5.

17 Freisleben, E, et al, Vox Sanguinis, 1961, 6, 304.

$18 \mathrm{Jandl}, \mathrm{J}$ H, Fournal of Laboratory and Clinical Medicine, 1960, 55, 663.

19 Brodeur, M T H, et al, Circulation, 1965, 32, 570.

20 Westring, D W, Annals of Internal Medicine, 1966, 65, 203.

${ }^{21}$ Morse, E E, et al, in 19th Annual Meeting of American Association Blood Banks. Los Angeles, 1966.

\title{
Use of prazosin in management of hypertension in patients with chronic renal failure and in renal transplant recipients
}

\author{
J R CURTIS, F J A BATEMAN
}

British Medical fournal, 1975, 4, 432-434

\section{Summary}

Prazosin was used in combination with other antihypertensive drugs in the successful management of hypertension in seven patients with chronic renal failure and six renal transplant recipients, also with chronic renal failure. The addition of small doses of prazosin (mean $3 \mathrm{mg} /$ day) to the antihypertensive regimen produced significant falls in systolic and diastolic blood pressures in both the lying and standing positions. The standing blood pressures were significantly lower than the lying blood pressures during prazosin treatment. Neither the mean blood urea concentrations nor the mean plasma creatinine concentrations changed significantly during prazosin administration. Chromium-51 edetic acid clearances did not change significantly during prazosin treatment in the seven patients in whom it was measured.

\footnotetext{
Department of Medicine, Charing Cross Hospital Medical School, London

J R CURTIS, MD, FRCP, senior lecturer and consultant nephrologist

Pfizer Limited, Sandwich, Kent

F J A BATEMAN, MB, BS, medical director
}

Severe symptomatic postural hypotension occurred in one patient a week after starting prazosin $3 \mathrm{mg} / \mathrm{day}$. This hypotensive episode was associated with a transient and reversible deterioration in renal function. Another patient developed a rash while on prazosin but it was probably related to propranolol rather than prazosin. Prazosin is thus an effective antihypertensive drug in patients with chronic renal failure, and it may be used with a variety of other drugs. It should be used cautiously, however, since patients with chronic renal failure may respond to small doses, and significant postural falls in blood pressure may result. There was no evidence that the use of prazosin resulted in progressive deterioration in the residual renal function of the patients with chronic renal failure.

\section{Introduction}

Prazosin is a relatively new antihypertensive drug, which has been used in patients with normal renal function. ${ }^{1}$ We report here its use in combination with other antihypertensive drugs in the management of hypertension in patients with chronic renal failure. Preliminary observations suggested that patients with chronic renal failure might respond to relatively small doses of the drug and that use of the drug, at least in combination with others, was associated with significant postural falls in blood pressure and a slight fall in the ${ }^{51} \mathrm{Cr}$-edetic acid clearance. ${ }^{2}$ 